\title{
Characteristics and outcomes of older patients attending the emergency department at an academic university hospital
}

\section{Bir akademik üniversite hastanesinde acil servise başvuran yaşlı hastaların özellikleri ve sonuçları}

\author{
Yusuf Kenan Tekin ${ }^{1}$, Erdal Demirtaş ${ }^{1}$, Naim Nur ${ }^{2}$, IIllhan Korkmaz ${ }^{1}$
}

${ }^{1}$ Cumhuriyet University Medicine Faculty Emergency Department, Sivas Turkey

${ }^{2}$ Cumhuriyet University Medicine Faculty Public Health Department, Sivas Turkey

Corresponding author: Yusuf Kenan Tekin, MD, Cumhuriyet University Medicine Faculty Emergency Department, Sivas Turkey

E-mail: yktekin@hotmail.com

Received/Accepted: May 29, 2019 /June 26, 2019

Conflict of interest: There is not a conflict of interest.

\section{SUMMARY}

Objective: Because older populations have been increased significantly over the last decades globally, emergency departments (ED) have become a vital place in the care of older patients. Characterizing the usage of the ED by older patients will facilitate the qualifying planning activities in emergency care delivery.

Method: The retrospective data were extracted from a database and included all patients, aged 65 years or over, admitted to the ED between 1 January 2017- 31 December 2017.

Results: The rate of ED visits accounted for $16.1 \%$. A large majority of the ED visits were during the day shift (49.6\%), and in summer months (June-August $28.7 \%$ ). The most common diagnoses (18.4\%) were cardiovascular conditions. A large majority $(67.8 \%)$ of ED visits involved diagnostic imaging, and nearly half $(46.7 \%)$ of them received consultation services. Nearly one-third (31.3\%) of older patients were admitted to hospital following their ED visit. Hospital admission, length of stay in ED, having consulting service, involving some kind of diagnostic imaging and being triaged as urgent/emergent are more likely to be increased with age group.

Conclusions: ED visits increase with age and also the resource use intensity of the ED, including the length of stay, diagnostic imaging, consultation and admission to the hospital after an ED visit appears to increase with aging. Patterns of the ED usage were described in this study may be helpful in resource planning, or may provide an approach for the future the investigation involving improved or alternative care options for the older patient.

Keywords: Emergency service, geriatric patients
Yusuf Kenan Tekin
Erdal Demirtaş
Naim Nur
iD İlhan Korkmaz

ORCID IDs of the authors: Y.K.T. 0000-0001-8047-4836 E.D. 0000-0003-0853-0623 N.N. 0000-0002-7675-9342 İ.K. 0000-0001-5182-3136

\section{ÖZET}

Amaç: Dünyada son yıllarda yaşlı nüfusun sayısı önemli ölçüde arttı̆̆ından, acil servisler (AS) yaşlı hastaların bakımında hayati öneme sahip bir yer haline gelmiştir. Acil servisin yaşlı hastalar tarafından kullanımını belirlemek, acil bakım hizmetinin sunumundaki nitelikli planlama faaliyetlerini kolaylaştıracaktır.

Yöntem: 1 Ocak 2017-31 Aralık 2017 tarihleri arasında AS'e başvuran 65 yaş ve üzeri tüm hastalara ait veriler retrospektif olarak veri tabanından çıkarıldı.

Bulgular: AS ziyaretlerinin oranı \% 16,1'dir. AS ziyaretlerinin büyük çoğunluğu gündüz (\% 49.6) ve yaz aylarında (Haziran-Ağustos \% 28.7) yapıldı. En sık görülen tanı (\% 18.4) kardiyovasküler durumlardı. AS ziyaretlerinin büyük 
çoğunluğu $(\%$ 67,8) tanısal görüntülemeyi içermekteydi ve neredeyse yarısı (\% 46,7) konsültasyon hizmeti almıştır. Yaşlı hastaların yaklaşık üçte biri $(\%$ 31,3) AS ziyaretlerini takiben hastaneye yatırıldı. Hastaneye yatış, AS'de kalma süresi, konsültasyon isteme, acil / acil olarak istenen bazı tanısal görüntülemeyi içeren tetkikler yaş grubu ile artış olasılı̆̆ daha yüksektir.

Sonuç: AS ziyaretleri yaşla birlikte artmakta ve ayrıca AS'nin kalış süresi, tanı görüntüleme, konsültasyon ve bir AS ziyaretinden sonra hastaneye kabul de dahil olmak üzere kaynak kullanımı yoğunluğunun yaşlanma ile birlikte arttı̆̆ görülmektedir. AS kullanımının örnekleri bu çalışmada tarif edilmiştir. Kaynak planlamasında yardımcı olabilir veya yaş1ı hasta ileride yapılacak araştırmalar için geliştirilmiş veya alternatif bakım seçeneklerini içeren bir yaklaşım sağlayabilir

Anahtar sözcükler: Acil servis, geriatrik hastalar, hasta kabulü

\section{INTRODUCTION}

The aging of the population is a major public health concern which has been resulting from the effect of increased life expectancy in Turkey as in western countries ${ }^{1,2}$. The median age of the world population is estimated to reach to 38 years by 2050 from 27 years in $2000{ }^{3}$. Life expectancy in the Turkish population has also grown from 48 to 74 years between 1960 and 2011. As a result the proportion of elderly population estimates to rise to $21 \%$ in 2050 from $8 \%$ in 2014 , in Turkey ${ }^{4}$.

The growth in the absolute numbers of persons 65 years of age and older will potentially lead to an increase in the emergency department (ED) visits rates ${ }^{5-8}$. This tendency represents a significant challenge for the ED in the context of resource scarcity and restricted specific critical skills of emergency healthcare workers in caring for this population ${ }^{5-9}$.

Because of age-related changes and longstanding problem among them, older patients are more likely to be admitted to ED with more serious illnesses as measured by triage acuity, diagnostic work-up, and with more complex symptoms, which require more laboratory examinations. Moreover, older patients have a longer ED stay ${ }^{10,11}$. Despite this, higher rates of admissions to ED with an increased risk of adverse consequences such as early hospital readmission or mortality are a potentially preventable burden on ED ${ }^{12,13}$.

Providing information related to the age-specific burden on ED visits is a valuable tool for raising the awareness of healthcare managers in the context of impending demographic changes that have an important impact on the future utilization of health care resources. Additionally, providing this information is also valuable since it makes ED health providers aware of those patients' evolving needs.

Due to the limited data on geriatric patients (aged 65 years and above), in Turkey, and currently no method is used for data collection on presenting complaints, this study sought to investigate ED visits by older patients regarding mode of admission, triage level, schedule, and main reason for ED visit as well as their outcomes such as length of stay in the ED and ED discharge dispositions, at an academic hospital.

\section{MATERIAL AND METHODS}

\section{Study design and population}

This retrospective study examined hospital administrative data from all patients presenting to the ED of a university hospital in Sivas, Turkey. All geriatric patients (aged 65 years and above) presenting to EDs between 1 January 2017 and 31 December 2017 were eligible for inclusion. All visits during the study period were included. Multiple ED visits by the same patients were also included. The study was approved by the university research ethics committee.

ED of the university hospital is open 24 hours. The ED treats patients according to how serious their condition or health problem is. The total number of patients admitted annually in the ED of this university hospital is around 65,000 .

\section{Variables}

Hospital administrative data contain patient age, gender, date and time of ED visit, reasons for $\mathrm{ED}$ visit (presenting chief complaints), triage level, length of ED stay in hours, diagnosis, consulting services, and disposition (outpatient or hospital admission, death, other).

Length of stay (LOS) for each patient was defined as from the time registration to the time he leaves the ED. Only completed visits were included in the calculation of the average length of stay in the ED. Visits lasting lower than 15 minutes were excluded from calculations. 


\section{Statistical analysis}

Data analysis was undertaken with the Statistical Package of Social Science version 16.0. Software (SPSS Inc., Chicago, IL). Firstly, all data were exported to SPSS for subsequent data analyses. Then, categorical and quantitative data were expressed as percentages and as the mean \pm standard deviation, SD, respectively. Finally, older patients were divided into three groups; 65-74, 75-84, and $\geq 85$. Significant differences in the characteristics between three groups and differences by gender were assessed by using the chi-square test for nominal data. A P value of less than 0.05 was considered statistically significant.

\section{RESULTS}

During the study period, the total number of ED visits in the university hospital was
64,508 , of which 10,371 were patients aged 65 and older $(16.1 \%)$. The overall number of 10,371 visits by older patients was included in the analysis.

Hourly distributions of ED admission by older patients was presented in Figure 1. A large majority of the older patient's ED visit $(49.6 \%)$ was observed during the day shift (08:00-16:00 hours) while their visiting late at night shift (22:00-6:00 hours) was only a minority $(16.8 \%)$. As presented in Figure 1, seasonal distribution of ED visits for older patients showed a slight predominance in summer (June-August 28.7\%,) compared to spring (March-May 26.0\%), autumn (September-November 24.4\%) or winter (December-February $20.9 \%$ ).

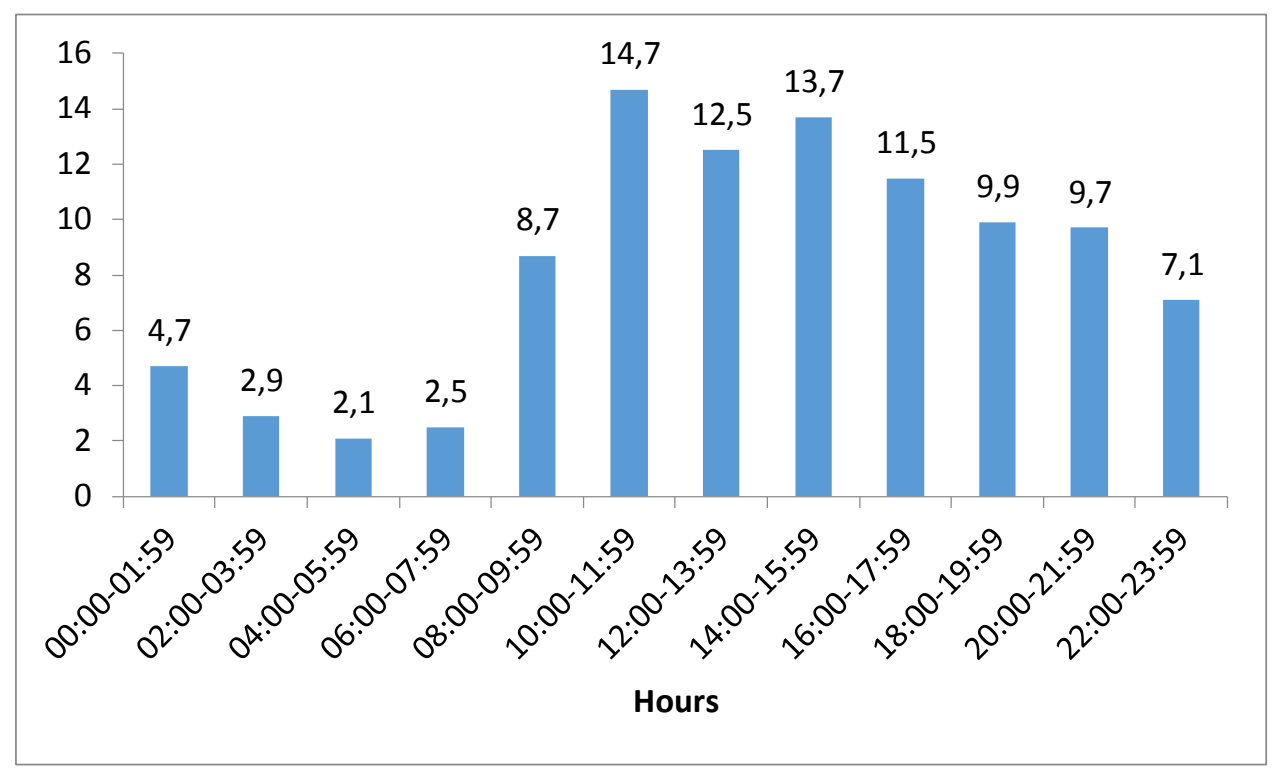

Figure 1: Hourly distributions of ED admission by older patients

Table 1 summarises the characteristics of ED visits by older patients. Almost all patients (99.9\%) had an ambulance as the mode of arrival. Shortness of breath $(25.8 \%)$ was the most common presenting complaints followed by chest pain $(18.7 \%)$, and general weakness (17.4\%), and $90.9 \%$ of older patients were triaged as urgent or emergent. More than twothirds $(67.8 \%)$ of ED visits involved any type of diagnostic imaging, and nearly half $(46.7 \%)$ of them received consultation services with other departments. The average length of stay was 7.5 hours (median $=8$ hours). The most $(64.7 \%)$ of the ED visits resulted in discharge, while $31.3 \%$ of them resulted in admission to hospital, and a small percentage of older patients died in the ED during the study period $(n=413$, death rate $4.0 \%)$.

The most common reasons for each ED visit by gender according to major clinical category were clustered in Table 2. According to Table 2, the most common diagnoses were cardiovascular conditions (18.4\%). Diagnoses related to the gastrointestinal and respiratory system constituted $12.3 \%$ and $10.2 \%$ of diagnoses, respectively. Any kind of trauma/injury constituted $8.1 \%$ of diagnoses, while neurological conditions constituted $7.0 \%$ of diagnoses. Furthermore, as presented in Table 2, 
diagnoses related to the respiratory system were more common in male patients, while any kind of trauma/injury was more present in female patients $(\mathrm{p}<0.001)$.

Table 1: Characteristics and outcomes of emergency department visits by older patients

\begin{tabular}{lll}
\hline Characteristics & Number & Percentage
\end{tabular}

\begin{tabular}{|c|c|c|}
\hline \multicolumn{3}{|l|}{ Gender } \\
\hline Female & 4902 & 47.3 \\
\hline Male & 5469 & 52.7 \\
\hline \multicolumn{3}{|l|}{ Age groups (year) } \\
\hline $65-74$ & 5441 & 52.5 \\
\hline $75-84$ & 3591 & 34.6 \\
\hline$>84$ & 1339 & 12.9 \\
\hline \multicolumn{3}{|l|}{ Mode of arrival } \\
\hline Ambulance & 10357 & 99.9 \\
\hline Other & 14 & 0.1 \\
\hline \multicolumn{3}{|c|}{ Number of emergency department visits } \\
\hline Once & 5422 & 52.3 \\
\hline More than one & 4949 & 47.7 \\
\hline \multicolumn{3}{|c|}{ The most common complaints about emergency department visits } \\
\hline Shortness of breath & 2676 & 25.8 \\
\hline Chest pain & 1939 & 18.7 \\
\hline General weakness & 1704 & 17.4 \\
\hline Abdominal pain & 1504 & 14.5 \\
\hline Any kind of trauma/injury & 965 & 9.3 \\
\hline Others & 1583 & 14.3 \\
\hline \multicolumn{3}{|l|}{ Triage level } \\
\hline Urgent/Emergent & 9431 & 90.9 \\
\hline Less urgent & 940 & 9.1 \\
\hline \multicolumn{3}{|c|}{ Diagnostic testing (Any imaging) } \\
\hline Presence & 7033 & 67.8 \\
\hline Absence & 3338 & 32.2 \\
\hline \multicolumn{3}{|l|}{ Consulting service } \\
\hline Yes & 4845 & 46.7 \\
\hline No & 5526 & 53.3 \\
\hline \multicolumn{3}{|c|}{ Length of stay in the emergency department } \\
\hline$\leq 8$ hours & 7118 & 61.8 \\
\hline$>8$ hours & 3253 & 38.2 \\
\hline \multicolumn{3}{|l|}{ Disposition } \\
\hline Hospital admission & 251 & 31.3 \\
\hline Home discharge & 6707 & 64.7 \\
\hline Dead in-ED & 413 & 4.0 \\
\hline
\end{tabular}


Table 2: The most common reasons for emergency department visit by older patients

\begin{tabular}{|c|c|c|c|c|}
\hline \multirow[t]{2}{*}{ Disorder/Illness Category } & \multirow{2}{*}{$\begin{array}{l}\text { Total } \\
(\mathrm{n}, \%)\end{array}$} & Female & Male & \multirow{2}{*}{$\begin{array}{c}\text { P value } \\
\text { (Chi-square test) }\end{array}$} \\
\hline & & $(\mathrm{n}, \%)$ & $(\mathbf{n}, \%)$ & \\
\hline Cardiovascular conditions & $1908(18.4)$ & $809(16.5)$ & $1099(20.1)$ & $<0.001$ \\
\hline Gastrointestinal conditions & $1272(12.3)$ & $632(12.9)$ & $640(11.7)$ & \\
\hline Respiratory conditions & $1056(10.2)$ & $378(7.7)$ & $678(12.4)$ & \\
\hline Any kind of trauma/injury & $838(8.1)$ & $466(9.5)$ & $372(6.8)$ & \\
\hline Neurological conditions & $725(7.0)$ & $309(6.3)$ & $416(7.6)$ & \\
\hline Other & $4572(44.0)$ & $2308(47.1)$ & $2264(42.4)$ & \\
\hline
\end{tabular}

Table 3: Characteristics of emergency department visits for older patients by age groups

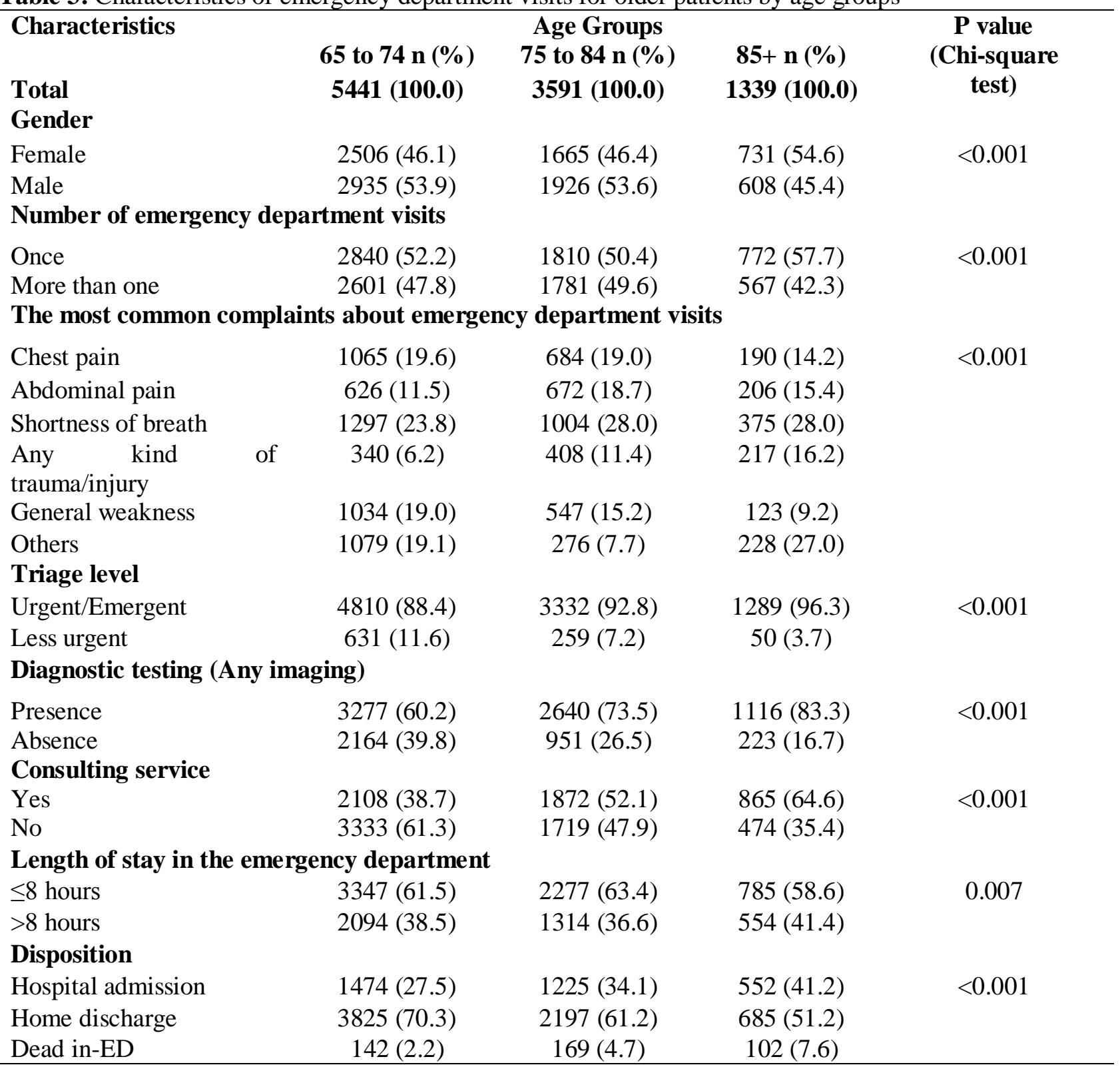


Table 4: Characteristics of emergency department visits for older patients by gender

\begin{tabular}{|c|c|c|c|}
\hline \multirow[t]{2}{*}{ Characteristics } & \multicolumn{2}{|c|}{ Gender } & \multirow{2}{*}{$\begin{array}{c}\text { P value } \\
\text { (Chi-square test) }\end{array}$} \\
\hline & Female (n, \%) & Male (n, \%) & \\
\hline Total & $4902(100.0)$ & $5469(100.0)$ & \\
\hline \multicolumn{4}{|c|}{ Number of emergency department visits } \\
\hline Once & $2625(53.5)$ & $2797(51.1)$ & 0.014 \\
\hline More than one & $2277(46.5)$ & $2672(48.9)$ & \\
\hline \multicolumn{4}{|c|}{ The most common complaints for emergency department visits } \\
\hline Shortness of breath & $1070(21.8)$ & $1606(29.4)$ & $<0.001$ \\
\hline Chest pain & $712(14.5)$ & $1227(22.4)$ & \\
\hline General weakness & $932(19.0)$ & $772(14.1)$ & \\
\hline Abdominal pain & $805(16.4)$ & $699(12.8)$ & \\
\hline Any kind of trauma/injury & $394(8.0)$ & $571(10.4)$ & \\
\hline Others & $989(20.3)$ & $594(10.9)$ & \\
\hline \multicolumn{4}{|l|}{ Triage level } \\
\hline Urgent/Emergent & $4436(90.5)$ & $4995(91.3)$ & 0.137 \\
\hline Less urgent & $466(8.5)$ & $474(8.7)$ & \\
\hline \multicolumn{4}{|c|}{ Diagnostic testing (Any imaging) } \\
\hline Presence & $3288(67.1)$ & $3745(68.5)$ & 0.127 \\
\hline Absence & $1614(32.9)$ & $1724(31.5)$ & \\
\hline \multicolumn{4}{|l|}{ Consulting service } \\
\hline Yes & $2199(44.9)$ & $2646(48.4)$ & $<0.001$ \\
\hline No & $2703(55.1)$ & $2823(51.6)$ & \\
\hline \multicolumn{4}{|c|}{ Length of stay in emergency department } \\
\hline$\leq 8$ hours & $3405(62.3)$ & $3004(61.3)$ & 0.306 \\
\hline$>8$ hours & $3374(37.7)$ & $1898(38.7)$ & \\
\hline \multicolumn{4}{|l|}{ Disposition } \\
\hline Hospital admission & $1409(28.7)$ & $1842(33.7)$ & $<0.001$ \\
\hline Home discharge & $3265(66.6)$ & $3442(62.9)$ & \\
\hline Dead in-ED & $228(4.7)$ & $185(3.4)$ & \\
\hline
\end{tabular}

In terms of age group, the characteristics of the ED visits by older patients are presented in Table 3. As a result of their ED visit, admission to hospital, length of stay in $\mathrm{ED}$, having consulting service, involving some kind of diagnostic imaging and being triaged as urgent/emergent are more likely to be increased with age group $(\mathrm{p}<0.0001$, respectively, only for the length of stay $(\mathrm{p}=0.007)$.
The ratio of visits associated with ED stay of greater than 8 hours increased with age group to a high of $41.4 \%$ for older patients aged 85 years and over. The most common diagnoses among patients 85 years and over were any kind of trauma/injury $(16.2 \%, \mathrm{p}<0.0001)$, while chest pain and general weakness were less common diagnoses among them $(14.2 \%, \mathrm{p}<0.0001$; $9.2 \%, \mathrm{p}<0.0001$, respectively). 
The proportion of repeated visits decreased with age group to a low of $42.3 \%$ for older patients aged 85 years and over $(\mathrm{p}<0.0001)$.

The characteristics of the ED visits, in terms of gender, are shown in Table 4. The proportion of repeated visits, having consulting services and hospital admission were more prevalent among male patients than female ones $(48.9 \%$ vs. $46.5 \%, \mathrm{p}<0.014 ; 48.4 \%$ vs. $44.9 \%, \mathrm{p}<0.001$; $33.7 \%$ vs. $28.7 \%, \mathrm{p}<0.001$, respectively). The most common complaints among patients aged 85 years and over related to any kind of trauma/injury were more common in male patients $(16.2 \%, \mathrm{p}<0.001)$, while complaints related to chest pain and general weakness were more present in female patients $(14.2 \%, \mathrm{p}<$ $0.001 ; 9.2 \%, \mathrm{p}<0.001$, respectively).

\section{DISCUSSION}

In our study, 10,371 ED visits by older patients were analyzed at an academic hospital and provided a detailed profile regarding differences in ED visits for these patients. Although nearly $12 \%$ of the current population living in Sivas is aged 65 years and over according to current census data, these people accounted for $16.1 \%$ of ED visits in Sivas, indicating greater ED usage by seniors (age 65 and older) compared with relatively younger ones. This finding was also comparable with the results of recent studies that show the rate of ED visits by older patients ranges from 3.6 to $28.0^{14,15}$. A large proportion of ED visits by older patients are triaged as urgent or emergent. Consume of healthcare resource for older patients in the ED is substantial, with more than two-thirds of visits (67.8\%) involving any type of diagnostic imaging and $46.7 \%$ involving consultation services with other departments. In this study, almost one-third of older patients (31.3\%), following their ED visit, was admitted to the hospital. This is expected, considering the ultimate goal of ED care is to create an appropriate place for patients with any emergency medical condition or life-threatening illness. However, as older patients more rely on ED services for timely access, it is significant to consider that the substantial, rapid, goal-oriented model of care delivery in the emergency services may not always be sufficient model or valuable substitute for primary care, especially for these patients that often need coordinated evaluation, continuity of care, and follow-up interval ${ }^{16}$.

Any kind of injuries is the most common definitive diagnosis in the ED visits among older patients. The possibility of hospital admission following the ED visit and prolonged a length of stay in ED visits increased with age, as did the possibility of receiving consultation from other departments or diagnostic testing. Increased intensity use of the ED resource may reflect the clinical complexity of disorders or illnesses that tend to emerge with age ${ }^{17}$. As mentioned above, the length of stay in the ED visits increases with age (Table 3). This is indicating, as the longer length of stay in the ED visits may expose these patients to a greater risk of negative outcomes relating to delayed diagnosis and medication errors ${ }^{11,18,19}$. Since the older population (aged 65 years and over) is a growing demographic in Turkey ${ }^{2}$, reducing the length of stay in the ED visits and assessing the effect of ED overcrowding on these people is crucial to achieving the goals of the ED care.

The findings of our study are confirming the results of other studies that have assessed patterns of ED usage by older patients. A similar ratio of ED visits in this current study resulted in admission to the hospital compared with others of the same age groups (20-50\%); however, the percentage of hospital admission varied across studies to a high of $30 \%$. A rate of ED visits in our study was related to some kind of diagnostic imaging, in line with other studies ${ }^{14,20,22}$. The rate of the most common presenting complaints and diagnoses (including trauma/injury, respiratory, and cardiovascular problems) in ED were also comparable to the data from recent reports in which indicated that diseases related to the cardiovascular and respiratory system, as well as traumas/injuries, constitute topranked reasons for ED visits ${ }^{20,22,23}$.

Contrary to previous research which reported that a large proportion of all ED visits were presented during the day shift and the winter months ${ }^{8,15,24}$ in our study similar to a study by Cigar from Turkey ${ }^{25}$, the highest proportion of ED visits was found during the working hours and the summer months. One explanation for this is that presentation in the ED during the working hours had a timely response to consultants and more easily available beds, but arrival to ED during the late hours may lead to delay in hospital admission because of excessive whole hospital occupancy for the said reasons. Also, such differences among studies may be attributed to geographical contexts in which the studies were conducted or variations in profiles of the older patients and differences in clinical characteristics of the older population. 
In this present study, consistent with resents studies from Pakistan and Swiss ${ }^{26,27}$, the majority of older patients were male. But, studies from Turkey and other setting reported the majority of the older patients were female ${ }^{15,23}$. Such differences related to gender might be explained by reflects of social or regional variations in profiles of the older population where the research is carried out.

In this present study, $4.0 \%$ of older patients were dead on the present in the ED visits and had no return of spontaneous circulation even after termination of resuscitation attempts according to Advanced Cardiac Life Support (ACLS) guidelines. A possible explanation is that prolonged illness may contribute to a failure to recognize and respond to the signs of deterioration in older patients. This needs to be investigated in future research.

The findings of this current study may be useful in the re-design of ED care services for older patients. For example, geriatric approaches to improving emergency-based care for older patients, such as geriatric evaluation, geriatric case-management, as well as re-designs of the physical condition of ED for older patients, may choose to focus resources to manage common medical problems in ED for this population, including trauma/injury, and may encompass strengthened self-management of acute exacerbations of respiratory and cardiovascular illness ${ }^{28-32}$. Also, because of older patients receiving numerous diagnostic imaging and consultations, it can be appropriate as a whole or in part to closely assess integration, coordination, and continuity of care in the ED for them.

Older patient attending ED are susceptible to negative outcomes related to ED visits, due to in part functional/social declines, comorbidities, and polypharmacy ${ }^{33,34}$. It has been indicated that the fast-paced, goal-oriented approaches of the ED may not be entirely conducive to the treatment of older patients, who often have more acute or complex presentations of diseases ${ }^{35}$. Therefore, descriptive information on ED usage is to determine older patients visiting the ED for health concerns that may be amenable to other types of health care supply that are more appropriate for the needs of this age group.

\section{Strengths and limitations}

Strengths of this current research include the comprehensive documentation of any kind of diagnostic imaging use and consultation service presented during ED visits, information which is often unavailable and may contain an inaccurate registration for large data sets. Furthermore, a more detailed examination of rates of admission and kind of illness for diagnostic classification was also provided.

This study had several limitations. First, it is not population-based but a single tertiary care study, which may not make it necessarily representative of the older adult population in Turkey. Second, the analysis of this study was limited to data sets related to the ED visit. Finally, we did not have any type of information related to patient's functional status, frailty, comorbidities, and polypharmacy that are well known to effect enabling ED factors (resource and support) and outcomes of the ED visits ${ }^{33,34}$.

\section{CONCLUSION}

In our study, ED visits increased with age and also resource use intensity of the ED, including the length of stay, diagnostic imaging, consultation, and admission to the hospital after an ED visit appears to increase with aging. Patterns of the ED usage were described in this study may be helpful in resource planning, or may provide an approach to the future investigation involving improved or alternative care options for older patients.

\section{REFERENCES}

1. Demographic change in the Euro Area. Projections and consequences. In: Bulletin Monthly (ed) European Central Bank (ECB). European Central Bank, Frankfurt am Main, pp. 49-64. 2006.

2. Turkish Statistical Institute, Demographic projections: 2008-2050, unpublished data (İn Turkish), 2009.

3. Goldstein JR. How the population age. In Uhlenberg, P. $\quad$ (ed). International. Handbook of Population Aging. Springer: New York: pp. 7-18. 2009.

4. Turkish Statistical Institute, Elderly statistics, 2014. Available from: http://www.turkstat.gov.tr/PreHaberBultenleri.d o?id=16057. Accessed on January 10, 2017.

5. Platts-Mills TF, Leacock B, Cabanas JG, Shofer FS, McLean SA. Emergency medical services use by the elderly: analysis of a statewide database. Prehosp Emerg Med 2010;14:329-33.

6. Braes T, Moons P, Lipkens P, Sterckx W, Sabbe M, Fleming J, et al. Screening for risk of 
unplanned readmission in older patients admitted to hospital: predictive accuracy of three instruments. Aging Clin Exp Res 2010;22(4):345-51.

7. Yenal S, Keser G, Mandıracıoğlu A, Yalçın MA, Bayram B, Akçiçek F, The determination of the status of emergency department use by elderly patients and of the indicators for ambulance use. Turkish Journal of Geriatrics 2018;21(2):109-17.

8. Keskinoğlu P, Inan F. Analysis of emergency department visits by elderly patients in an urban public hospital in Turkey. J Clin Gerontol Geriatr 2014;5:127-31.

9. Vilpert S, Jaccard-Ruedin $\mathrm{H}$, Trueb $\mathrm{L}$, Monod-Zorzi S, Yersin B, Büla C . Emergency department use by oldest-old patients from 2005 to 2010 in a Swiss University hospital. BMC Health Serv Res 2013;13:344.

10. Aminzadeh F, Dalziel WB. Older adults in the emergency department: a systematic review of patterns of use, adverse outcomes, and effectiveness of interventions. Ann Emerg Med 2002;39:238-47.

11. Samaras N, Chevalley T, Samaras D, Gold G. Older patients in the emergency department: a review. Ann Emerg Med 2010;56:261-9.

12. McCusker J, Verdon J. Do geriatric interventions reduce emergency department visits? A systematic review. J Gerontol A Biol Sci Med Sci 2006;61:53-62.

13. McCusker J, Dendukuri N, Tousignant P, Verdon J, Poulin de Courval L, Belzile E. Rapid two-stage emergency department intervention for seniors: impact on continuity of care. Acad Emerg Med 2003; 10(3): 233-43.

14. Latham LP, Ackroyd-Stolarz S. Emergency department utilization by older adults:

a descriptive study. Can Geriatr J 2014;17(4):118-25. Doi: 10.5770/cgj.17.108.

15. Gulacti U, Lok U, Celik M, Aktas N, Polat $\mathrm{H}$. The ED use and non-urgent visits of elderly patients. Turk J Emerg Med 2016;16(4):141-5.

16. Wilber ST, Gerson LW. Emergency department care. In: Halter JB, Ouslander JG, Tinetti ME, et al., editors. Hazzard's geriatric medicine and gerontology, $6^{\text {th }}$ edition. New York: McGraw-Hill; 2009.

17. Gruneir A, Silver MJ, Rochon PA. Emergency department use by older adults: a literature review on trends, appropriateness, and consequences of unmet health care needs. Med Care Res Rev 2011;68(2):131-55.

18. Trzeciak S, Rivers EP. Emergency department overcrowding in the United States: an emerging threat to patient safety and public health. Emerg Med J 2003;20(5):402-5.

19. Meurer WJ, Potti TA, Kerber KA, Sasson C, Macy ML, West BT, et al. Potentially inappropriate medication utilization in the emergency department visits by older adults: analysis from a nationally representative sample. Acad Emerg Med 2010;17(3):231-7.

20. Pines JM, Mullins PM, Cooper JK, Feng LB, Roth KE. National trends in emergency department use, care patterns, and quality of care of older adults in the United States. J Am Geriatr Soc 2013;61(1):12-7.

21. Downing A, Wilson R. Older people's use of accident and emergency services. Age Ageing 2005;34(1):24-30.

22. Carron PN, Mabire C, Yersin B, Büla C. Nursing home residents at the emergency department: a 6-year retrospective analysis in a Swiss academic hospital. Int Emerg Med 2017;12(2):229-37.

23. Li G, Lau JT, McCarthy ML, Schull MJ, Vermeulen M, Kelen GD. Emergency department utilization in the United States and Ontario, Canada. Acad Emerg Med 2007;14(6):582-4.

24. Pitts SR, Niska RW, Xu J, Burt CW. National hospital ambulatory medical care Survey: 2006 emergency department summary. Natl Health Stat Rep 2008;7:1-38.

25. Çiğşar G, Akkuş Y, Elnare, G Esma, Erdemir Öztürk E, Palas MB. Aetiology of emergency department admission of the elderly: a retrospective study in Kars. Turk J Geriatr 2016;19(1):19-26.

26. Fayyaz J, Khursheed M, Mir MU, Khan U. Pattern of emergency department visits by elderly patients: study from a tertiary care hospital, Karachi. BMC Geriatr 2013;13:83.

27. Shaha M, Gmuer S, Schoenenberger AW, Gerber FS, Exadaktylos AK. Trends and characteristics of attendance at the emergency department of a Swiss university hospital: 2002-2012. Swiss Med Wkly 2015;145:w14141.

28. Bissett M, Cusick A, Lannin NA. Functional assessments utilised in emergency 
departments: a systematic review. Age Ageing 2013;42(2):163-72.

29. Sinha SK, Bessman ES, Flomenbaum N, Left B. A systematic review and qualitative analysis to inform the development of a new emergency department-based geriatric case management model. Ann Emerg Med 2011;57(6):672-82.

30. McCusker J, Verdon J, Vadeboncoeur A, Lévesque JF, Sinha SK, Kim KY, et al. The elder-friendly emergency department assessment tool: development of a quality assessment tool for emergency departmentbased geriatric care. J Am Geriatr Soc 2012;60(8):1534-39.

31. Conroy SP, Ansari K, Williams $M$ Laithwaite E, Teasdale B, Dawson J, et al. A controlled evaluation of comprehensive geriatric assessment in the emergency department: The 'Emergency Frailty Unit'. Age Ageing 2014;43(1):109-14.
32. Beauchet $\mathrm{O}$, Launay $\mathrm{CP}$, Fantino $\mathrm{B}$, Lerolle N, Maunoury F, Annweiler C. Screening for elderly patients admitted to the emergency department requiring specialized geriatric care. J Emerg Med. 2013;45(5):73945.

33. McCusker J, Ionescu-Ittu R, Ciampi A, Vadeboncoeur A, Roberge D, Larouche D, et al. Hospital characteristics and emergency department care of older patients are associated with return visits. Acad Emerg Med 2007;14(5):426-33.

34. Gray LC, Peel NM, Costa AP Burkett E, Dey AB, Jonsson PV, et al. Profiles of older patients in the emergency department: findings from the interRAI Multinational Emergency Department Study. Ann Emerg Med. 2013;62(5):467-74.

35. Grief CL. Patterns of ED use and perceptions of the elderly regarding their emergency care: A synthesis of recent research. J Emerg Nurs. 2003;29(2):122-26. 